
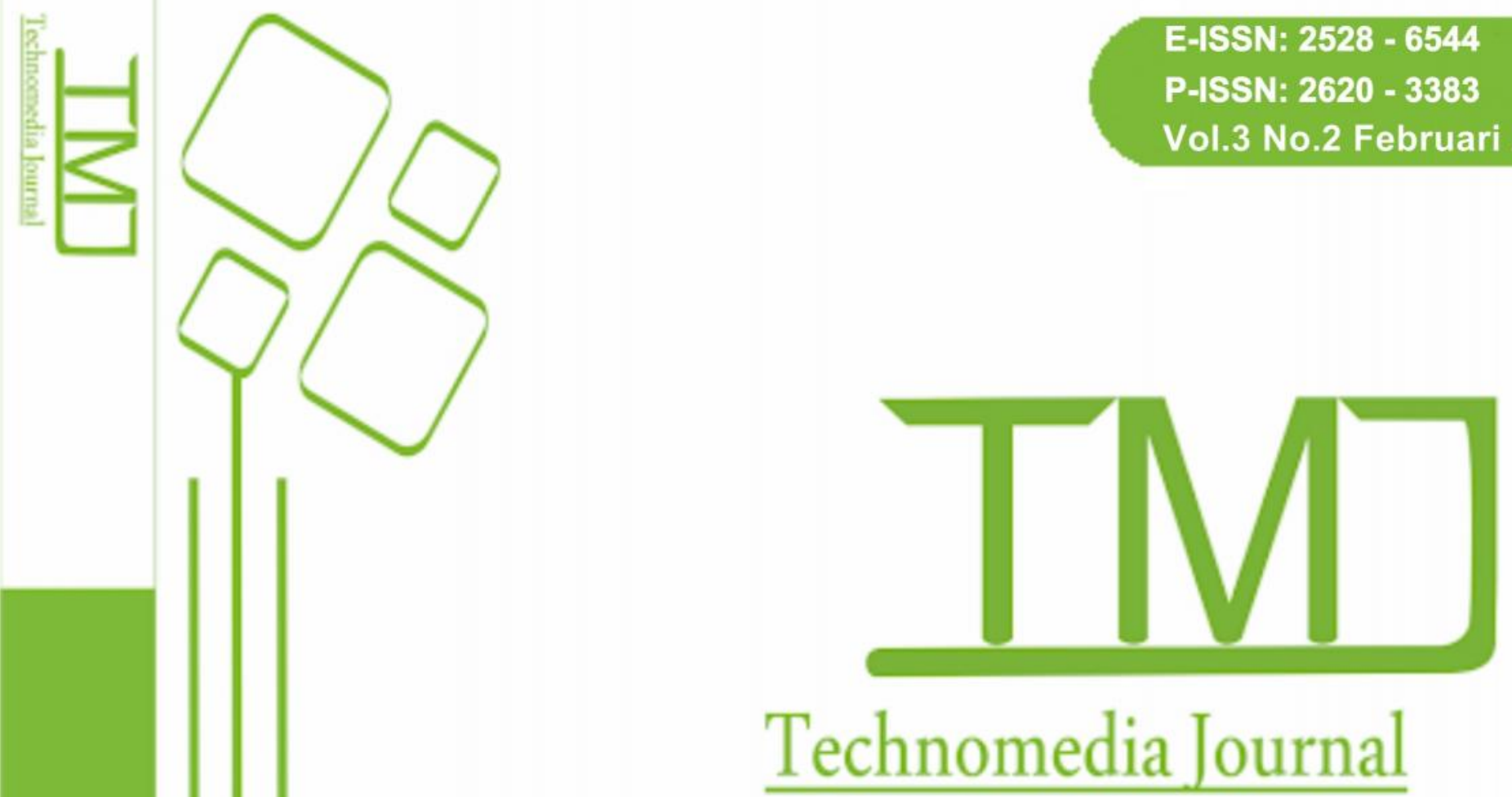

Technomedia Journal

iLearning Journal Center (iJC)

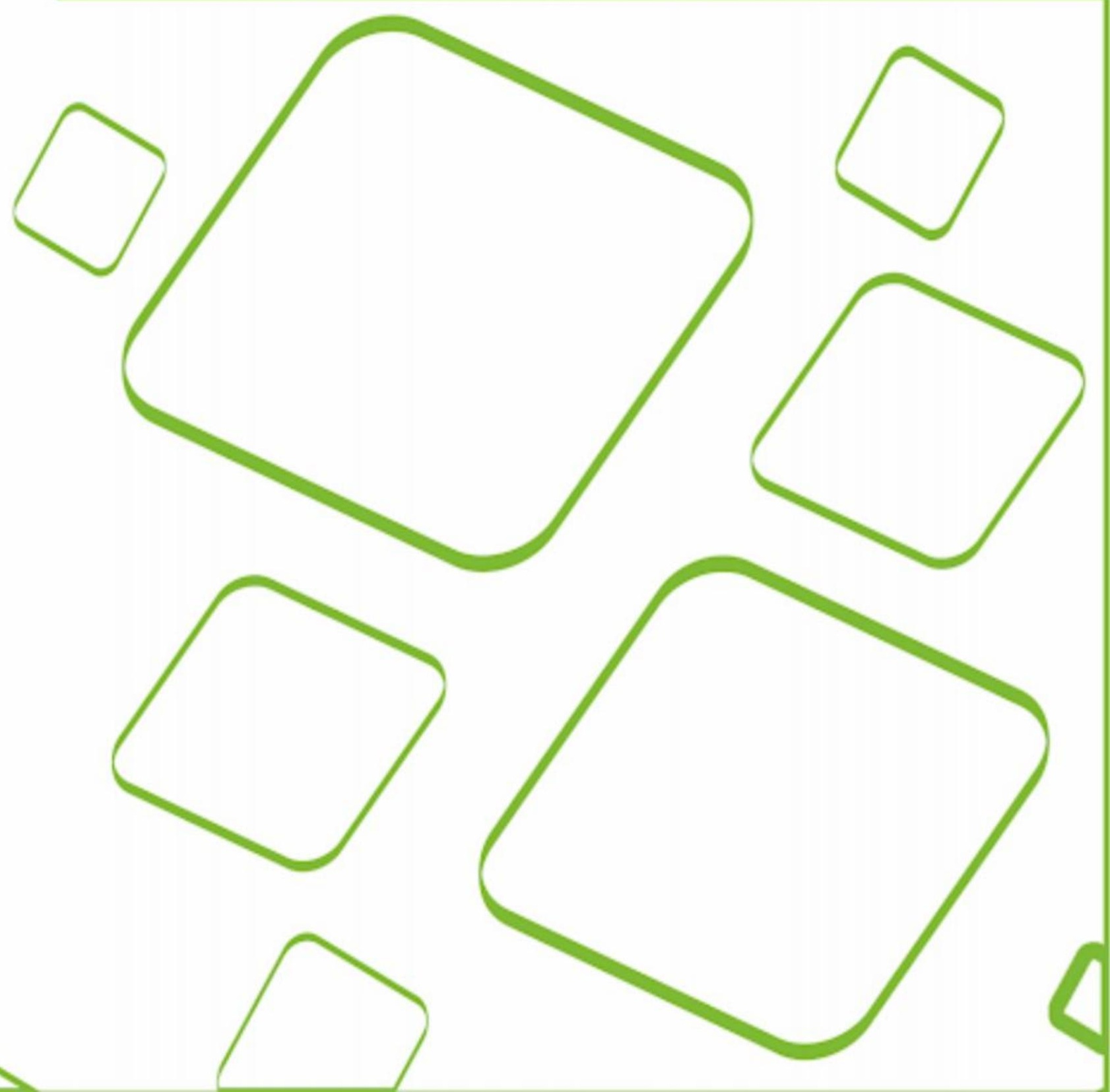




\title{
Analisa Sistem Informasi Manajemen Sumber Daya Manusia Pada Proses Rekrutmen, Demosi dan Mutasi di PT. Yasunli Abadi Utama Plastik
}

\author{
Oleh Soleh ${ }^{1}$ \\ Wahyu Hidayat ${ }^{2}$ \\ Fitri Widya Rustanti $\mathrm{S}^{3}$ \\ Dosen STMIK Raharja ${ }^{1,2}$ \\ Mahasiswa Jurusan Sistem Informasi, STMIK Raharja, Tangerang ${ }^{3}$ \\ e-mail:oleh.soleh@raharja.info ${ }^{1}$,wahyu@raharja.info ${ }^{2}$,widya@raharja.info ${ }^{3}$
}

\begin{abstract}
ABSTRAK
Dibutuhkan suatu sistem yang baik untuk memonitor semua aktifitas, produktifitas, kedisiplinan serta jenjang karir karyawan dalam sebuah perusahaan yang sedang berkembang, karena kondisi saat ini semua hal tersebut masih dilakukan secara manual. Hal ini dapat menyebabkan kesalahan dalam mengambil keputusan kepada karyawan tersebut. Untuk memudahkan pihak perusahaan dalam mengambil keputusan dan tindakan terhadap karyawan tersebut, maka diperlukan sebuah sistem yang dapat membuat rangkuman dari hasil kinerja karyawan dari sisi aktifitas, produktifitas, kedisiplinan serta jenjang karier. Hal ini perlu dilakukan analisa dalam sistem Sumber Daya Manusia (SDM) atau yang lebih sering dikenal dengan Human Resource dan untuk metode analisa yang digunakan saat ini menggunakan tiga metode, observasi, studi pustaka dan analisa. Obyek yang digunakan dalam permasalahan ini adalah PT. Yasunli Abadi Utama Plastik. Target pencapaian dalam hal ini adalah untuk melakukan tindakan dan mengambil keputusan terhadap karyawan yang berprestasi atau yang tidak berprestasi dengan cepat dan tepat.
\end{abstract}

Kata Kunci: Karyawan, Sistem, Sumber Daya Manusia, Human Resource, Yasunli Abadi Utama Plastik.

\section{ABSTRACT}

It takes A good system is needed to monitor all activities, productivity, discipline and career path of employees in a developing company, because the current conditions are all done manually. This can cause errors in making decisions for these employees. To facilitate the company in making decisions and actions against these employees, we need a system that can make a summary of the results of employee performance in terms of activity, productivity, discipline and 
career path. This needs to be analyzed in the Human Resources (HR) system or more commonly known as Human Resource and for the analytical method used today uses three methods, observation, literature and analysis. The object used in this problem is PT. Yasunli Abadi Utama Plastik. The target of achievement in this case is to take action and make decisions against high achieving or quick-achieving employees.

Keywords: System, Human Resources, Human Resource, Yasunli Abadi Utama Plastik.

\section{PENDAHULUAN}

Pada era globalisasi saat ini, teknologi informasi menempati peranan penting dalam kehidupan masyarakat. Disemua bidang kehidupan masyarakat, perkembangan sistem berkambang sangat baik. Dengan adanya perkembangan tersebut, semua informasi sudah dilakukan secara komputerisasi. Dalam perkembangan tekhnologi, sistem yang sebelumnya dilakukan manual sekarang sudah berubah menjadi sistem yang otomatis. Teknologi informasi akan mengolah dan mendapatkan informasi secara cepat, tepat dan akurat. Saat ini sudah menjadi kebutuhan bahwa sistem komputerisasi dapat memberi kemudahan dalam mencari informasi yang diinginkan, dan keamanan data pun lebih terjamin.

Dalam kondisi seperti sekarang ini sangat kurang maksimal jika dalam melakukan pengolahan dan pencarian data seorang pegawai masih menggunakan sistem yang manual. Sulitnya pengelolaan dan pencarian data seorang pegawai dikarenakan sistem yang ada di PT. Yasunli Abadi Utama Plastik masih berupa dokumen word dan excel, sehingga waktu yang diperlukan lebih banyak. PT. Yasunli Abadi Utama Plastik membutuhkan sumber daya manusia yang berkualitas dan bermutu tinggi. Oleh sebab itu, Manajemen Sumber Daya Manusia (HRD) harus mampu mengelola dan menangani masalah yang berhubungan dengan bagian tersebut. Manajemen Sumber Daya Manusia (HRD) bertanggung jawab dalam proses penambahan/rekrutmen karyawan, dimulai dari pemasangan iklan untuk menjaring calon karyawan, interview hingga proses seleksi. Untuk pengembangan karir dan produktifitas karyawan, maka perlu dilakukan beberapa promosi, transfering, demosi yang dianggap perlu buat karyawan yang bersangkutan. Melakukan pengembangan diri, pembinaan, pelatihan, potensi, mental, serta keterampilan dan pengetahuan karyawan sesuai dengan standarisasi yang ada diperusahaan. Melakukan sanksi jika terjadi pelanggaran yang dilakukan oleh perusahaan sesuai dengan peraturan atau kebijakan perusahaan.

Keberhasilan perusahaan dapat dilihat dari sumber daya manusia yang dipekerjakan diperusahaan tersebut. Diluar sumber daya manusia yang ada, perusahaan juga memerlukan adanya Sistem Informasi Sumber Daya Manusia (Sistem Human Resource/Human Resource Information System). Program atau bisa disebut dengan aplikasi yang mengelola dan melakukan pengolahan data manajemen SDM untuk mengambil atau menentukan keputusan yang akan 
dibuat dan biasa disebut dengan Human Resources Information System (HRIS, atau Decision Support System dengan menyediakan informasi sumber daya manusia yang dibutuhkan.

\section{METODE PENELITIAN}

Pada penulisan jurnal saat ini menggunakan 4 tahapan yang digunakan adalah sebagai berikut:

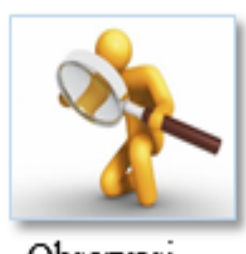

Observasi

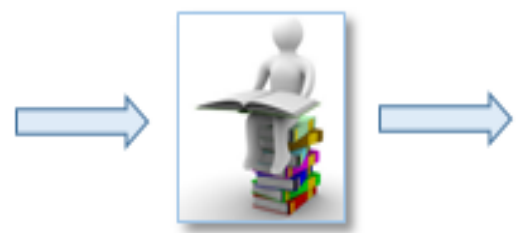

Study Pustaka

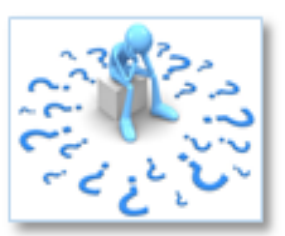

Analisa

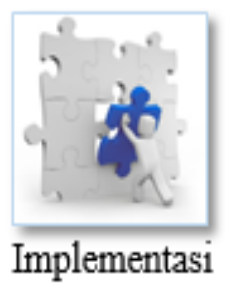

Gambar 1. Metode Penelitian

\section{Keterangan:}

\section{a. Metode Observasi}

Sesuai dengan penulis Nida, Yessy Frecilia. "Metode Observasi" pada: https://widuri.raharja.info/index.php/Metode_Observasi. diakses tanggal 10 November 2018. Metode observasi atau pengamatan dilakukan dengan cara melakukan pengamatan langsung kepada proses berjalannya suatu sistem. Tujuan dilakukannya observasi yaitu untuk mendeskripsikan setting yang dipelajari, aktivitas-aktivitas yang berlangsung, orangorang yang terlibat dalam aktivitas dan makna kejadian dilihat dan perpekstif mereka terlibat dalam kejadian yang diamati tersebut. Penulis melakukan pengamatan langsung ke PT. Yasunli Abadi Utama Plastik. Metode ini dilakukan untuk mendapatkan dan pengumpulkan data guna memenuhi informasi untuk menganalisa dan membentuk pembuatan sistem baru.

\section{b. Metode Studi Pustaka}

Banyak penelitian yang dilakukan sebelumnya mengenai penelitian ilmiah bisa dijadikan sumber data. Diantaranya ada 6 (enam) buku dan penelitian yang dijadikan sumber pustaka, yaitu:

1. Penelitian yang dilakukan oleh Al Husain, Abdul Haqy Aji Prastian dan Andre Ramadhan dari Perguruan Tinggi Raharja dalam bentuk laporan jurnal TECHNOMEDIA JOURNAL Vol 2 No 1 (2017) yang berjudul "Perancangan Sistem Absensi Online Menggunakan Android Guna Mempercepat Proses Kehadiran Karyawan Pada PT. Sintech Berkah Abadi". Sistem absensi yang dikembangkan menggunakan teknologi yang ada saat ini seperti android memungkinkan perusahaan mendapat keuntungan yang sangat banyak, karena akan mempermudah dan mempercepat 
karyawan dalam hal absensi. Hal ini juga berpengaruh pada laporan yang akan dibuat oleh HRD, karena data yang ada di sistem tertata rapi sehingga untuk membuat laporan akan sangat mudah. Dalam hal merancang sistem absensi online berbasis android diperlukan metode yang baik dan penelitian yang berlanjut agar kedepannya sistem ini sangat bermanfaat bagi perusahaan.

2. Penelitian yang dilakukan oleh Al Husain, Abdul Haqy Aji Prastian dan Andre Ramadhan dari Perguruan Tinggi Raharja dalam bentuk laporan jurnal TECHNOMEDIA JOURNAL Vol 1 No 2 (2017) yang berjudul "Perancangan Sistem Absensi Online Menggunakan Android Guna Mempercepat Proses Absensi”. Dengan adanya sistem absensi online ini, karyawan dapat mengoptimalkan pekerjaan dengan sangat baik. Karena sistem absensi ini diakses sangat mudah dan waktu pun dapat digunakan secara efisien.

3. Penelitian yang dilakukan oleh Saidani dan Arifi dalam bentuk laporan Jurnal Riset Manajemen Sains Indonesia, 3(1), 1-22 yang berjudul "Pengaruh kualitas produk dan kualitas layanan terhadap kepuasan konsumen dan minat beli pada ranch market". Berdasarkan penelitian ini perlu dibutuhkan kinerja yang baik dan maksimal dari karyawan dan manajemen sumber daya manusia, yang mana keadilan organisasional dan komitmen organisasional termasuk di dalamnya, untuk membuat sumber daya manusia menjadi keuntungan bagi perusahaan mendasari penelitian ini penting untuk dilakukan. Oleh karena itu, dilakukanlah penelitian untuk menguji pengaruh keadilan organisasional terhadap kinerja karyawan dengan komitmen organisasional sebagai variabel intervening.

4. Penelitian yang dilakukan oleh Harris Kristanto dari Universitas Kristen Petra dalam bentuk laporan jurnal JMK, VOL. 17, NO. 1, MARET 2015, 86-98 yang berjudul "KEADILAN ORGANISASIONAL, KOMITMEN ORGANISASIONAL, DAN KINERJA KARYAWAN". Berdasarkan hasil penelitian yang dilakukan di CV Tanaya Fiberglass, maka dapat diambil kesimpulan untuk keadilan organisasi sangat berpengaruh positif terhadap komitmen organisasional tersebut. Keadilan organisasi dengan komitmen organisasi sebagai variabel intervening berpengaruh positif terhadap kinerja karyawan. Keadilan organisasi sangat berpengaruh positif terhadap kinerja karyawan dan target perusahaan.

5. Penelitian yang dilakukan oleh Billy Renaldo Potale, Viktor Lengkong dan Silcyljeova Moniharapon dari Universitas Sam Ratulangi Manado dalam bentuk laporan Jurnal Berkala Ilmiah Efisiensi Volume 16 No. 04 Tahun 2016 yang berjudul "PENGARUH PROSES REKRUTMEN DAN SELEKSI TERHADAP KINERJA KARYAWAN PADA PT BANK SULUTGO”. Pada penelitian ini membahas pengaruh antara rekrutmen dan seleksi dengan kinerja karyawan khususnya pada PT. Bank SulutGo, 
ternyata diketahui ada pengaruh yang positif dan signifikan antara rekrutmen dan seleksi terhadap kinerja karyawan. Dengan demikian hipotesis terbukti. Variabel yang paling dominan mempengaruhi kinerja karyawan khususnya pada PT. Bank SulutGo adalah seleksi, alasannya karena variabel seleksi memiliki nilai koefisien regresi yang terbesar jika dibandingkan dengan variabel rekrutmen, sehingga hipotesis kedua dapat dikatakan terbukti.

6. Penelitian yang dilakukan oleh Suwardi dan Joko Utomo dari Universitas Muria Kudus, dalam bentuk jurnal Analisis Manajemen Vol. 5 No. 1 Juli 2011 yang berjudul "PENGARUH MOTIVASI KERJA, KEPUASAN KERJA, DAN KOMITMEN ORGANISASIONAL TERHADAP KINERJA PEGAWAI”. Pada penelitian ini dapat disimpulkan Variabel motivasi dengan dimensi usaha, tujuan organisasi, dan kebutuhan terbukti secara signifikan memiliki pengaruh positif dan signifikan terhadap kinerja pegawai Sekretariat Daerah Kabupaten Pati dengan item paling baik adalah tantangan pekerjaan dapat diartikan bahwa para pegawai merasa bahwa pekerjaan di Sekretariat Daerah Kabupaten Pati menantang dan menyenangkan.

Dari 6 (enam) Literature Review yang telah dijelaskan diatas, sudah banyak penelitian yang dilakukan mengenai rekruitmen karyawan dan metode pengembangan karyawan dan ada pula yang membahas tentang produktifitas karyawan serta lingkungan kerja yang menyenangkan. Akan tetapi dapat disimpulkan belum ada penelitian yang dilakukan mengenai manajemen sumber daya manusia.

\section{c. Metode Analisa.}

Metode yang ketiga yaitu metode analisa. Setelah dianalisa untuk proses manajemen sumber daya manusia yang sudah berjalan di PT. YASUNLI ABADI UTAMA PLASTIK masih menggunakan metode manual sehingga besar kemungkinan terjadi kesalahan dalam pengelolaan manajemen sumber daya manusia tersebut.

\section{d. Implementasi.}

Pada penelitian ini sudah dilakukan perencanaan sistem yang akan diterapkan untuk proses Manajemen Sumber Daya Manusia di PT. YASUNLI ABADI UTAMA PLASTIK dalam bentuk diagram Unified Modeling Language (UML).

\section{HASIL DAN PEMBAHASAN}

Prosedur rekrutmen, wawancara, hingga seleksi karyawan baru. Prosedur ini dimulai dari menempel pengumuman lowongan kerja di pintu gerbang utama ataupun papan informasi ditiaptiap departemen. Kemudian HRD mulai melakukan seleksi berkas lamaran yang masuk memanggil calon karyawan untuk mengikuti tes tertulis, tes kesehatan, dan tes administrasi. 
Prosedur demosi, promosi dan mutasi karyawan. Prosedur ini dimulai dari kegiatan rutin rekap absensi karyawan tiap semester (6 bulan). Dari rekap absensi tersebut akan terlihat

karyawan mana yang sering tidak masuk kerja dengan alasan tertentu. Karyawan yang memiliki absensi yang kurang baik akan mendapatkan sanksi yang berupa mutasi ataupun demosi yang sesuai dengan kebutuhan perusahaan. Dan sebaliknya, karyawan yang memiliki absensi sangat baik memiliki kesempatan untuk diikutkan dalam promosi jabatan.

a. Rancangan prosedur sistem berjalan pada Use Case Diagram.

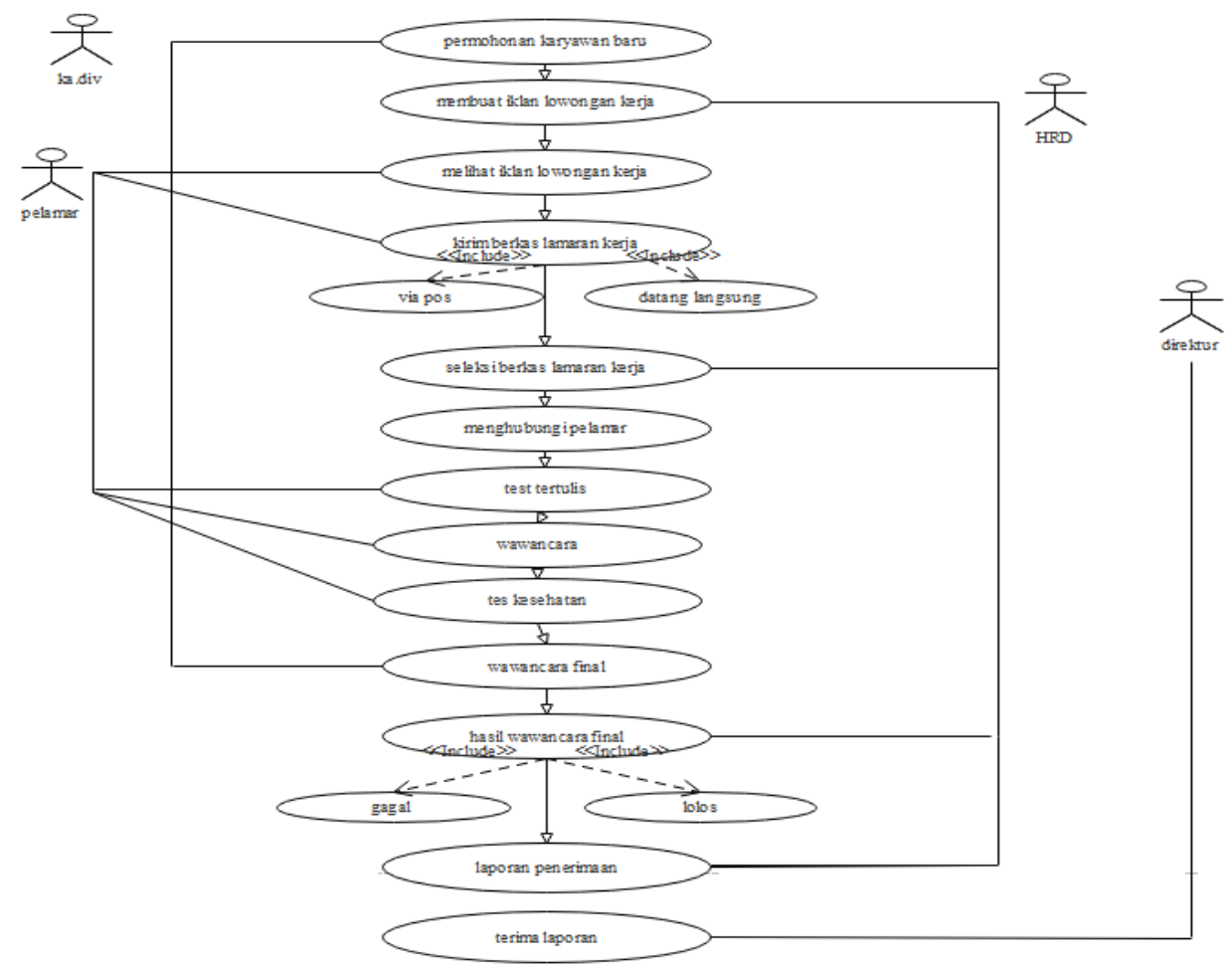

Gambar 2. Use Case Diagram Rekrutmen dan Seleksi Karyawan Baru

Berdasarkan Use Case Diagram Rekrutmen dan seleksi karyawan baru diatas terdapat :

a. 1 sistem yang berjalan untuk terdapat menggambarkan prosedur rekrutmen dan seleksi karyawan baru.

b. Terdapat 4 aktor yaitu Ka.Div, HRD, pelamar, Direktur/pimpinan

c. Terdapat 17 use case yang dikerjakan 


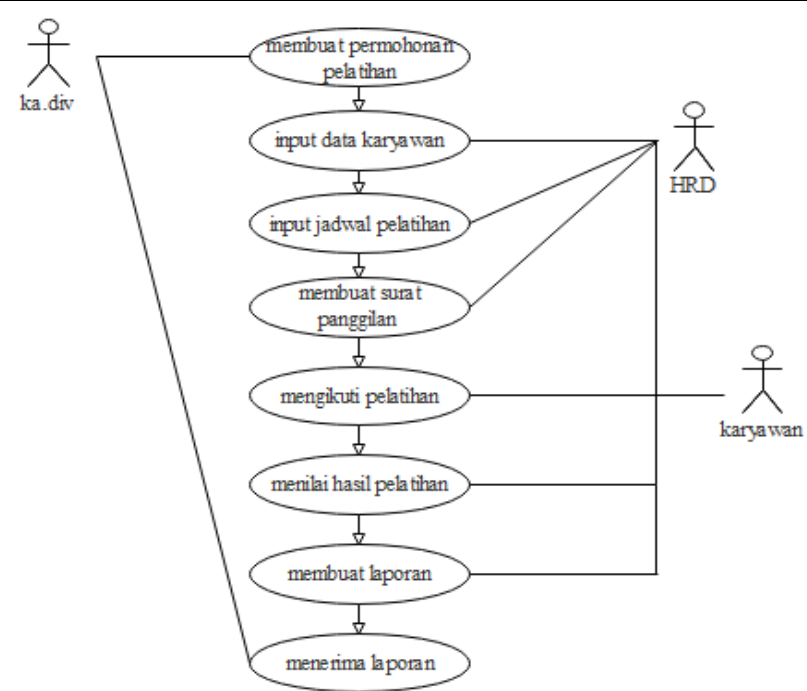

Gambar 3. Use Case Diagram Promosi, Demosi dan Mutasi Karyawan

Berdasarkan Use Case Diagram Promosi, Demosi dan Mutasi Karyawan diatas terdapat:

a. 1 sistem berjalan yang menggambarkan prosedur Promosi, Demosi dan Mutasi karyawan

b. Terdapat 3 aktor yaitu Ka.div, HRD, direktur/pimpinan

a. Terdapat 13 use case yang dikerjakan

b. Rancangan prosedur sistem berjalan pada Activity Diagram.

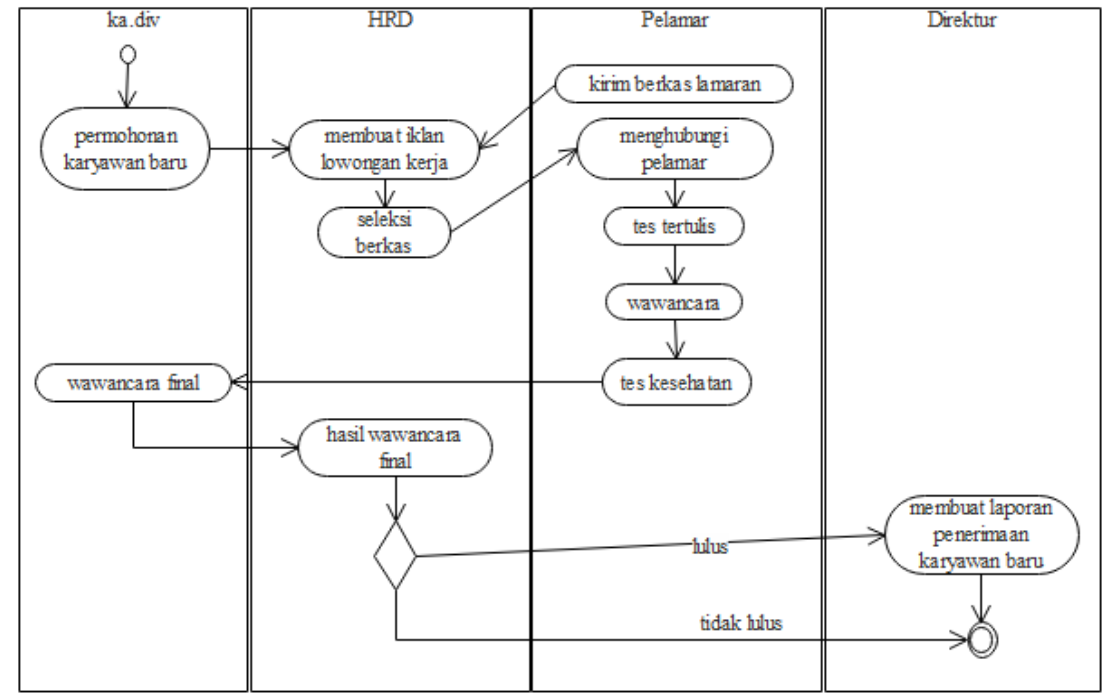

Gambar 4. Activity Diagram Rekrutmen dan seleksi karyawan

Berdasarkan gambar Activity Diagram Rekrutmen dan seleksi karyawan diatas terdapat:

a. 1 initial node, objek yang diawali. 
b. 11 action, state yang menggambarkan eksekusi dari suatu aksi.

c. 1 final state, objek yang diakhiri

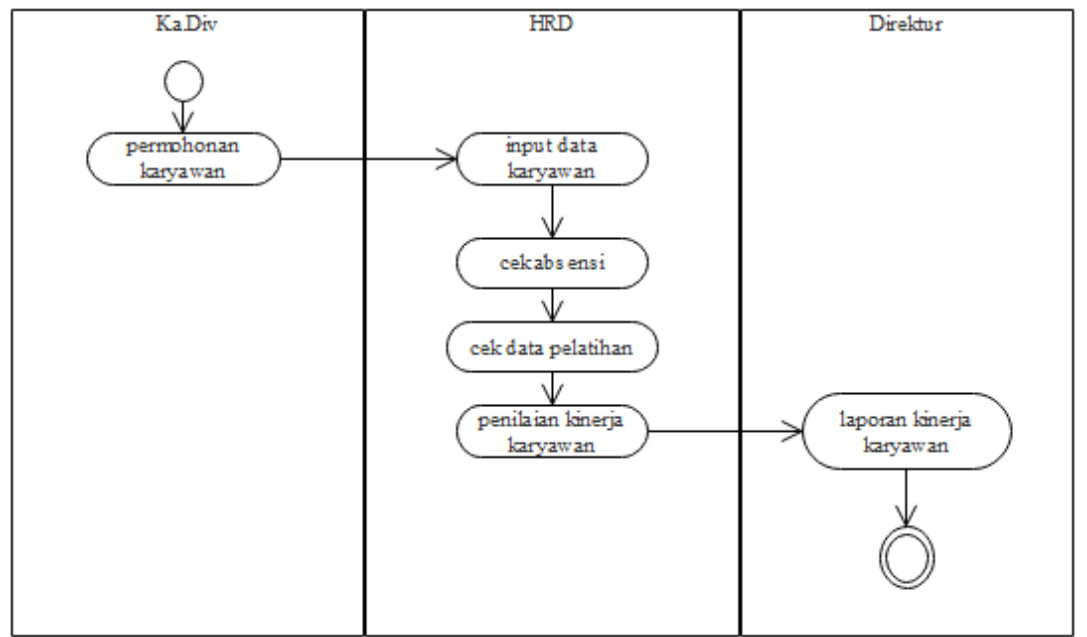

Gambar 5. Activity Diagram Promosi, Demosi dan Mutasi Karyawan

Berdasarkan gambar Activity Diagram Promosi, Demosi dan Mutasi karyawan diatas terdapat :

a. 1 initial node, objek yang diawali

b. 6 action, state yang menggambarkan eksekusi dari suatu aksi

a. 1 final state, objek yang diakhiri.

c. Rancangan prosedur sistem berjalan pada Sequence Diagram.

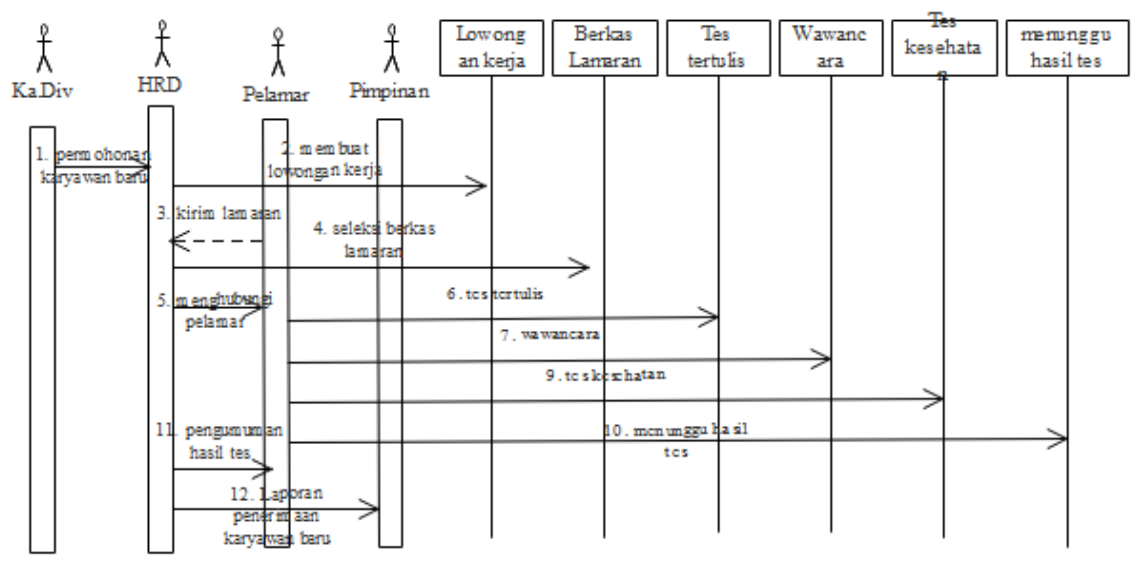

Gambar 6. Sequence Diagram Rekrutmen dan Seleksi Karyawan Baru

Berdasarkan gambar Sequence Diagram Rekrutmen dan Seleksi Karyawan Baru diatas terdapat:

a. 4 aktor yang melakukan kegiatan yaitu, Kadiv, HRD, Pelamar, Direktur/pimpinan 
b. 6 object life yang dikerjakan oleh actor.

a. 12 message yang merupakan urutan kegiatan untuk penyimpanan laporan

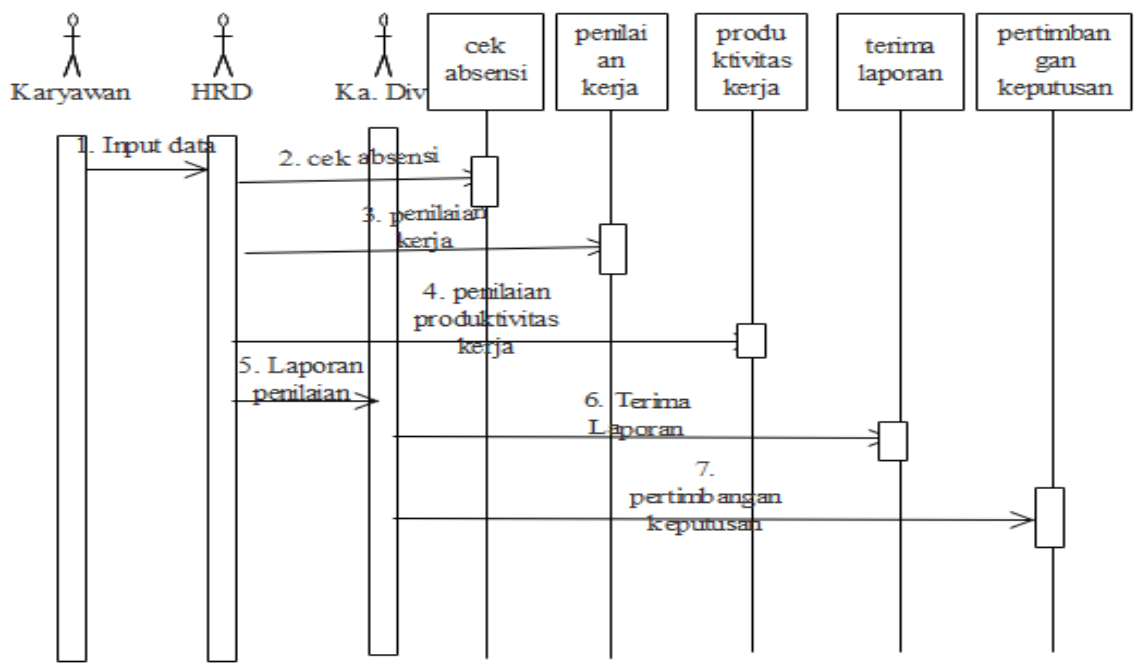

Gambar 7. Sequence Diagram Promosi, Demosi dan Mutasi Karyawan

Berdasarkan gambar Sequence Diagram Promosi, Demosi, dan Mutasi karyawan diatas terdapat:

a. 3 aktor yang melakukan kegiatan yaitu, Kadiv, HRD, karyawan

b. 5 object life yang dikerjakan oleh aktor

a. 7 message yang merupakan urutan kegiatan untuk penyimpanan laporan

\section{GRAFIK PENCAPAIAN}

1. Dengan adanya implementasi ini untuk proses Rekrutmen dan Seleksi Karyawan Baru bisa termonitor lebih mudah oleh bagian sumber daya manusia.

2. Dengan adanya implementasi ini untuk proses Demosi dan Mutasi Karyawan tidak menggunakan penilaian yang objektif, dikarenakan sudah ada ketentuan dan prosedur yang berlaku sesuai rencana sistem yang ada.

\section{KESIMPULAN}

Dari hasil analisis sistem informasi manajemen sumber daya manusia pada PT. Yasunli Abadi Utama Plastik yang telah dilakukan, maka dapat disimpulkan hal-hal sebagai berikut:

1. Sistem informasi manajemen sumber daya manusia yang belum terkomputerisasi. Karena tidak terintegrasinya data master karyawan dan yang ada pada bagian HRD, sehingga mengakibatkan kesulitan dalam mengupdate data secara keseluruhan yang berpengaruh terhadap data karyawan. 
2. Sistem informasi rekruitmen dan seleksi karyawan baru yang belum berjalan dengan baik, karena jumlah calon karyawan yang relatif banyak mengakibatkan perusahaan keliru dalam mendata karyawan. Hal tersebut terjadi karena adanya kekeliruan dalam memasukkan data atau variabel ke dalam komputer.

3. Masih adanya kendala dalam sistem promosi dan demosi karyawan.

Data-data yang berkaitan dengan informasi karyawan dapat dengan mudah diakses atau dibuka dan diubah oleh karyawan yang seharusnya tidak berhak melakukan pengubahan, sehingga mengakibatkan data mudah hilang maupun dimanipulasi.

\section{SARAN}

Penulisan jurnal ANALISA SISTEM INFORMASI MANAJEMEN SUMBER DAYA MANUSIA PADA PT. YASUNLI ABADI UTAMA PLASTIK adalah suatu proses analisa dan solusi untuk mengatasi administrasi yang selama ini dilakukan secara manual oleh bagian tertentu di perusahaan tersebut. Perlu dilakukan pembuatan sistem yang terkomputerisasi untuk mengurangi resiko kesalahan penginputan data. Akan tetapi, masih ada kekurangan dari sistem yang ditawarkan sesuai penjabaran diatas. Terdapat beberapa hal yang dapat dijadikan saran dari penulis untuk pengembangan berikutnya yaitu : adanya sebuah prototype system, table elisitasi dan juga databases untuk perencaan sistem yang akan diterapkan.

\section{DAFTAR PUSTAKA}

[1] Husain, A., Prastian, A. H. A., \& Ramadhan, A. (2017). Perancangan Sistem Absensi Online Menggunakan Android Guna Mempercepat Proses Kehadiran Karyawan Pada PT. Sintech Berkah Abadi. Technomedia Journal, 2(1), 105-116. 6.

[2] Husain, A., Prastian, A., Haqy, A., \& Ramadhan, A. (2017). Perancangan Sistem Absensi Online Menggunakan Android Guna Mempercepat Proses Absensi. Technomedia Journal, $1(2), 116-127 .$.

[3] Nida, Yessy "Metode $\quad$ Frecilia. Observasi". https://widuri.raharja.info/index.php/Metode_Observasi diakses tanggal 20 November 2018.

[4] Saidani, B., \& Arifin, S. (2012). Pengaruh kualitas produk dan kualitas layanan terhadap kepuasan konsumen dan minat beli pada ranch market. Jurnal Riset Manajemen Sains Indonesia, 3(1), 1-22.

[5] Kristanto, H. (2015). KEADILAN ORGANISASIONAL, KOMITMEN ORGANISASIONAL, DAN KINERJA KARYAWAN. JMK, VOL. 17, NO. 1, MARET 2015, 86-98. 
[6] Potale, B. R., Lengkong, L., \& Moniharapon, S. (2016). PENGARUH PROSES REKRUTMEN DAN SELEKSI TERHADAP KINERJA KARYAWAN PADA PT BANK SULUTGO. Jurnal Berkala Ilmiah Efisiensi Volume 16 No. 04 Tahun 2016.

[7] Suwardi, \& Utomo, J. (2011). PENGARUH MOTIVASI KERJA, KEPUASAN KERJA, DAN KOMITMEN ORGANISASIONAL TERHADAP KINERJA PEGAWAI. Analisis Manajemen Vol. 5 No. 1 Juli 2011. 